\section{'Achilles' Apple}

\section{Thomas Sotiropoulos ${ }^{1}$}

Pomology Institute, National Agricultural Research Foundation, P.O. Box

122, 59200 Naoussa, Greece

\section{Nikolaos Koutinas \\ Alexander Technological Educational Institute of Thessaloniki, Department of Crop Production, P.O. Box 141, 57400 Thessaloniki, Greece}

\section{Antonios Petridis}

School of Agriculture, Aristotle University of Thessaloniki, 54124 Thessaloniki, Greece

Additional index words. cultivar description, fruit breeding, Malus domestica
The apple (Malus domestica Borkh.) cultivar Achilles is a natural mutation of the and fruit weight of 'Achilles' are not different from 'Firiki'. However, the significant advantage is that the red color covers a higher surface than in the cultivar Firiki. For the climatic conditions of northern Greece, 'Achilles' fruits mature at the third week of September. The fruit flesh of the cultivar Achilles is white, aromatic, crisp, and juicy. Fruit firmness and titratable acidity of the cultivar Achilles at harvest were similar to 'Firiki', whereas total soluble solids and total antioxidant power were higher. The fruit maintains its firmness, juiciness, and flavor very well in standard cold storage $\left(0\right.$ to $\left.1{ }^{\circ} \mathrm{C}\right)$ for $\approx 7$ months.

\section{Origin}

In Greece, the total apple production in 2008 was $234,700 \mathrm{t}$ and the cultivated acreage was 12,000 ha (FAO, 2008). The main apple cultivars grown in Greece are several clones of the cultivars Red Delicious, Golden Delicious, and Granny Smith that correspond to $\approx 90 \%$ of the total apple production. Firiki is a Greek local cultivar that has a characteristic aroma and taste and is preferred by a significant percentage of consumers. The cultivar Achilles is a natural mutation of the cultivar Firiki that was detected by the researcher T. Sotiropoulos in 1999 in Imathia prefecture (northern Greece). The mutated shoot was propagated initially by grafting a few buds on the apple rootstock M26. The evaluation and the description were done over 3 consecutive years (2007 to 2009: from the fifth until the seventh year of the trees) in a private orchard that is located in Naoussa (northern Greece, long. $22^{\circ} 12^{\prime} 0^{\prime \prime} \mathrm{E}$; lat. $40^{\circ} 29^{\prime} 04^{\prime \prime} \mathrm{N}$; elevation 270 $\mathrm{m})$. The soil of the experimental orchard at a depth of 0 to $60 \mathrm{~cm}$ was characterized as a clay loam, slightly alkaline ( $\mathrm{pH} 7.21)$, with low electrical conductivity $\left(0.82 \mathrm{mS} \cdot \mathrm{cm}^{-1}\right)$ and

Received for publication 27 Jan. 2010. Accepted for publication $24 \mathrm{Feb} .2010$.

${ }^{1}$ To whom reprint requests should be addressed; e-mail thosotir@otenet.gr. Greek local cultivar Firiki. The productivity low organic matter $(1.64 \%)$ content. Soil nutrient contents were $\left(\mathrm{mg} \cdot \mathrm{kg}^{-1}\right)$ : phosphorus 31.9 , potassium 296, calcium 505, magnesium 132 , manganese 16 , zinc 4.3 , iron 22 , and boron $0.28\left(\mathrm{mg} \cdot \mathrm{L}^{-1}\right)$ in the saturation extract of the soil. Data from the nearest meteorological station showed that the mean maximum temperature of the experimental area is $38^{\circ} \mathrm{C}$ in July and $9.5^{\circ} \mathrm{C}$ in January, whereas the mean minimum temperature in January is $-7^{\circ} \mathrm{C}$.

The scope of this research was to provide information about the new cultivar Achilles and to evaluate it in comparison with its parent cultivar regarding productivity and some fruit quality attributes.

\section{Description}

Leaves and trees. The trees in the experimental orchard were trained as a palmette at distances $3.5 \times 2 \mathrm{~m}$ apart. The leaves of the cultivar Achilles have the following dimensions: length $8.6 \mathrm{~cm}$, width $4.2 \mathrm{~cm}$, length of leaf petiole $1.9 \mathrm{~cm}$, and thickness of leaf petiole $2 \mathrm{~mm}$. Leaf fall occurs in early December. When grafted on M26 rootstock, this cultivar is moderately vigorous with good productivity that is stable from year to year. First fruiting occurred at the third year of the trees. However, when grafted on MM 106 rootstock, trees are vigorous with an upright habit. Full bloom of the cultivar Achilles occurs between 16 and 22 Apr., whereas full bloom of the cultivars Golden Delicious and Granny Smith occurs 12 to 20 and 13 to 18 Apr., respectively. Unopened flowers of the cultivar Achilles are medium pink at full balloon stage, whereas at full bloom, the petals are mainly white with a slight medium pink blush. The productivity of 'Achilles' was not significantly different from 'Firiki' (Table 1). Leaf nutrient concentrations were within the range proposed by Bergmann (1988) (data not shown).

Fruits. Fruit characteristics presented are mean values of 30 fruits per tree from 35 trees (five replications $\times$ seven trees) of each cultivar taken over a period of 3 consecutive years. The experimental layout was a randomized complete block design including five replications of two cultivars, each one including seven trees. The significance of the differences between means was evaluated by using Fisher's analysis of variance at $P<0.05$ carried out by SPSS Version 17 (SPSS Inc., Chicago, IL).

Fruits of the cultivar Achilles (Fig. 1) have a red skin color and are oblong with the following dimensions: length $6.6 \mathrm{~cm}$, width $5.4 \mathrm{~cm}$, pedicel length $1.5 \mathrm{~cm}$, and pedicel thickness $1.5 \mathrm{~mm}$. Length/width ratio values of 'Achilles' fruit were not significantly different from 'Firiki' (Table 1). Although the shape of 'Achilles' is similar to 'Firiki', the significant advantage is that the red color covers greater surface than in the cultivar Firiki (Fig. 2). The width and depth of the calyx cavity of the cultivar Achilles is 1.95 $\mathrm{cm}$ and $0.9 \mathrm{~cm}$, respectively. Fruits are covered by a light waxy layer and have an average number of small inconspicuous lenticels. For the climatic conditions of northern Greece, fruits of 'Achilles' mature at the third week of September (20 to 25), like its parent, 'Firiki'. With regard to harvest maturity indices, the most common used are the total soluble solids content and flesh firmness. Fruit weight of 'Achilles' is not significantly different from that of 'Firiki' (Table 1). 'Achilles' trees, like its parent 'Firiki', have a very low percentage of preharvest fruit drop $(1 \%)$, expressed as a percentage of a total number of fruits per tree. Thinning is necessary so the trees can set annually heavy crops and to avoid biennial bearing. Bearing occurs mainly on spurs. Two harvesting dates are required with $\mathrm{a} \approx 1$-week interval. Fruits of 'Achilles', like its parent 'Firiki', do not show symptoms of epidermal russeting. The fruit flesh of the cultivar Achilles is white, aromatic, crisp, and juicy. Fruit firmness [(N) measured with an Effegi penetrometer with a 11-mm tip (Effegi Model FT 327, Alfonsine, Italy)] of the cultivar Achilles at harvest was not different from 'Firiki' (Table 1). The total soluble solids content $\left[\left({ }^{\circ}\right.\right.$ Brix $)$ measured with an Atago PR1 electronic refractometer (Atago Co. Ltd., Tokyo, Japan)] of 'Achilles' was higher than
Table 1. Productivity, fruit weight, fruit firmness, fruit length/maximum width, and total soluble solids of the apple cultivars Achilles and Firiki grafted on M26 rootstock over a period of 3 years (from the fifth until the seventh year of the trees).

\begin{tabular}{lccccc}
\hline Cultivar & $\begin{array}{c}\text { Productivity } \\
(\mathrm{kg} / \text { tree })\end{array}$ & $\begin{array}{c}\text { Fruit wt } \\
(\mathrm{g})\end{array}$ & $\begin{array}{c}\text { Fruit } \\
\text { firmness }(\mathrm{N})\end{array}$ & $\begin{array}{c}\text { Fruit length/ } \\
\text { width }\end{array}$ & $\begin{array}{c}\text { Total soluble } \\
\text { solids }\left({ }^{\circ} \text { Brix }\right)\end{array}$ \\
\hline Achilles & $40.13 \mathrm{a}^{*}$ & $164.12 \mathrm{a}^{\mathrm{z}}$ & $72.59 \mathrm{a}$ & $1.11 \mathrm{a}$ & $14.11 \mathrm{a}$ \\
Firiki & $37.80 \mathrm{a}$ & $160.21 \mathrm{a}$ & $70.63 \mathrm{a}$ & $1.05 \mathrm{a}$ & $12.90 \mathrm{~b}$ \\
\hline
\end{tabular}

${ }^{\mathrm{z}}$ Means of 30 fruits per tree of 35 trees (five replications $\times$ seven trees) for 3 years. Fruits were pooled from all trees.

*Means followed by the same letter in the same column are not significantly different (Fisher's F; $P<0.05$ ). 


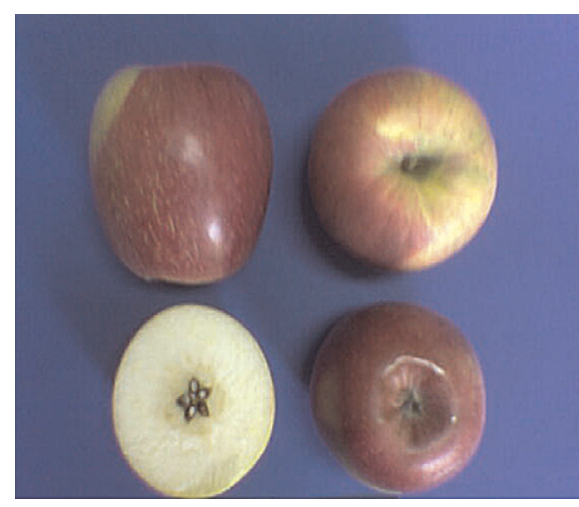

Fig. 1. Fruits of the cultivar Achilles.

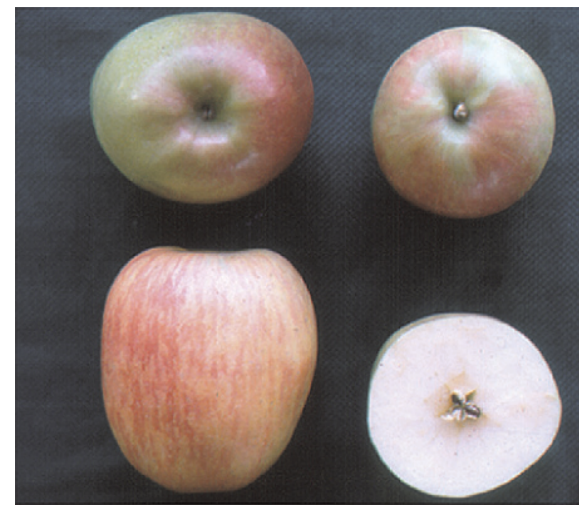

Fig. 2. Fruits of the cultivar Firiki.

that of 'Firiki' (Table 1). The pH of juice was not different for the two cultivars (Table 2). Total titratable acidity $[(\%)$ measured as

Table 2. Total titratable acidity, $\mathrm{pH}$ of juice, and total antioxidant power of the apple cultivars Achilles and Firiki grafted on M26 rootstock over a period of 3 years (from the fifth until the seventh year of the trees).

\begin{tabular}{lccc}
\hline Cultivar & $\begin{array}{c}\text { Total titratable } \\
\text { acidity }(\% \text { malic acid })\end{array}$ & pH of juice & $\begin{array}{c}\text { Total antioxidant power } \\
(\mu \mathrm{mol} \text { ascorbic acid equivalent } / \mathrm{g} \text { fresh wt) }\end{array}$ \\
\hline Achilles & $2.20 \mathrm{a}^{\mathrm{z} *}$ & $3.20 \mathrm{a}$ & $14.16 \mathrm{a}^{\mathrm{y}}$ \\
Firiki & $2.14 \mathrm{a}$ & $3.30 \mathrm{a}$ & $12.00 \mathrm{~b}$ \\
\hline
\end{tabular}

${ }^{\mathrm{z}}$ Means of 30 fruits per tree of 35 trees (five replications $\times$ seven trees) for 3 years. Fruits were pooled from all trees.

${ }^{\mathrm{y}}$ Measurement of 1 year.

*Means followed by the same letter in the same column are not significantly different (Fisher's F; $P<0.05$ ).

described by Koukourikou-Petridou et al. (2007)] was not different for the two cultivars (Table 2). Ascorbic acid content of the cultivar Achilles was $7.1 \mathrm{mg} / 100 \mathrm{~g}$ fresh weight. Total antioxidant power (Benzie and Strain, 1996) of 'Achilles' is considered high and higher than 'Firiki'. Drogoudi et al. (2008) studied the antioxidant power of seven apple cultivars and concluded that the cultivar Firiki had higher antioxidant power of the flesh than the cultivars Golden Delicious, Fuji, Granny Smith, Mutsu, Starkcrimson, and Jonagored.

During storage, fruits of 'Achilles', like its parent 'Firiki', do not show symptoms of the physiological disorder "bitter pit" or "external browning." The only postharvest physiological disorder noticed, during some years of the study, is the "water core." The fruit maintains firmness, juiciness, and flavor very well in standard cold storage ( 0 to $1{ }^{\circ} \mathrm{C}$ ) for $\approx 7$ months.

In conclusion, 'Achilles' seems to be a promising apple cultivar as a result of its high quality and nutritional value that may eventually replace 'Firiki'.

\section{Availability}

'Achilles' apple will be in the near future registered in the official list of the Greek Ministry of Agriculture.

\section{Literature Cited}

Benzie, I.F. and J. Strain. 1996. The ferric reducing ability of plasma (FRAP) as a measure of 'antioxidant power': The FRAP assay. Anal. Biochem. 239:70-76.

Bergmann, W. 1988. Ernahrungsstorungen bei Kulturpflanzen. 2nd Ed. Gustav Fischer, Jena, Germany.

Drogoudi, P., Z. Michailidis, and G. Pantelidis. 2008. Peel and flesh antioxidant content and harvest quality characteristics of seven apple cultivars. Sci. Hort. 115:149-153.

FAO. 2008. $<$ http://www.fao.org $>$.

Koukourikou-Petridou, M., D. Voyatzis, D. Stylianidis, T. Sotiropoulos, and I. Therios. 2007. Effects of some growth regulators on pre and after storage quality of Red Chief Delicious apples. Eur. J. Hort. Sci. 72:8-11. 